Old Dominion University

ODU Digital Commons

\title{
Developing Lifelong Learning With Heutagogy: Contexts, Critiques, and Challenges
}

Robert L. Moore

Old Dominion University, robmoorephd@gmail.com

Follow this and additional works at: https://digitalcommons.odu.edu/stemps_fac_pubs

Part of the Educational Technology Commons, Online and Distance Education Commons, and the Social and Philosophical Foundations of Education Commons

\section{Original Publication Citation}

Moore, R. L. (2020, 2020/07/02). Developing lifelong learning with heutagogy: Contexts, critiques, and challenges. Distance Education, 41(3), 381-401. https://doi.org/10.1080/01587919.2020.1766949

This Article is brought to you for free and open access by the STEM Education \& Professional Studies at ODU Digital Commons. It has been accepted for inclusion in STEMPS Faculty Publications by an authorized administrator of ODU Digital Commons. For more information, please contact digitalcommons@odu.edu. 


\title{
Developing lifelong learning with heutagogy: contexts, critiques, and challenges
}

\author{
Robert L. Moore (ID)
}

STEM Education and Professional Studies, Old Dominion University, Norfolk, VA, United States of America

\begin{abstract}
This systematic review investigated the contexts, critiques, and challenges of using heutagogy (Hase \& Kenyon, 2000), an emerging instructional approach that emphasizes the self-determination of learners, to develop lifelong learners. A total of 33 peer-reviewed publications published between 2000 and 2019 were aggregated and synthesized, and findings explored the role that technology played in supporting the heutagogical approach and learning environments and contexts that have used heutagogy. The review concludes with the critiques and challenges of the heutagogical approach.
\end{abstract}

\section{ARTICLE HISTORY}

Received 28 November 2019

Accepted 4 May 2020

\section{KEYWORDS}

heutagogy; online learning

environments; online learning; adult learners;

lifelong learning; self-

determined learners

\section{Introduction}

As the COVID-19 global pandemic demonstrated, our society can be completely changed in a matter of months. In a short period of time, daily lives have been completely changed. People needed to be able to adapt quickly and apply their knowledge and skills in an increasingly technology-driven society (Ashton \& Elliott, 2007; Blaschke \& Hase, 2015). As the pandemic demonstrated, these adaptations happened in a multitude of contexts, such as restaurant workers becoming delivery drivers and parents becoming homeschool instructors. Another area that saw a significant shift is in education as school districts and universities shut down face-to-face instruction and transitioned to online instruction (Hodges et al., 2020; Meckler et al., 2020). The pandemic response demonstrated just how impactful online learning can be. Millions of students literally overnight began receiving their instruction online, and millions more new adult learners turned to online resources seeking information such as how to provide instruction to their children.

Eachempati et al. (2017) argued that traditional educational methods are falling short in preparing learners to be successful in modern workplace environments. Hase (2009) further asserted that the linear approach of our current educational system does not align with the dynamic and nonlinear nature of workplace environments. One way to prepare for these evolving environments is by helping learners see learning as a continuous rather than a static process (Abraham \& Komattil, 2017; Blaschke, 2019). It is through lifelong learning that we can best prepare learners to seek out and find answers to the questions that arise as they move through their lives. With this shift to viewing learning as a continuous process, we must also look to shift to utilizing more learner-centered 
instructional approaches to prepare for lifelong learning (Ashton \& Newman, 2006; Blaschke, 2012; Carr et al., 2018; Pal \& Roy, 2019).

The COVID-19 pandemic response in the United States highlighted the challenges of the instructor-centered instructional approach and the potential benefits of a more student-centered approach (Barack, 2020). Across the country, school districts and institutions of higher education decided that having students in schools or on campus was too dangerous and shifted from face-to-face to online instruction (Hill, 2020; Hodges et al., 2020; Meckler et al., 2020). However, there was little to no preparation for the students, teachers, or parents for how to handle this type of instruction (Brenan, 2020; Hodges et al., 2020; Tate, 2020). Previously, parents sent their children off to school and let the teachers (and, by proxy, the school districts and administrators) determine how the days should be structured and what content should be covered. With the sudden shift to distance education, parents suddenly needed to take a more active role in the direct instruction of their children (Brenan, 2020; Tate, 2020). And many struggled. We saw adult learners turning to web-based or on-demand asynchronous learning environments to continue their education or improve their current life situation, further highlighting the need for instructional approaches that enable these learners to reach their educational goals (Blaschke, 2012, 2019; Canning, 2010; Canning \& Callan, 2010). Social media and online forums were flooded with parents overly burdened by the demands of handling this new instructional responsibility (Noguchi, 2020; Reynolds, 2020). They felt that they needed guidance and direction (instructordriven) and ultimately when they did not receive that guidance, they began to demonstrate student-centered problem-solving. They sought out resources in online forums, they formed social media support groups, and began to think creatively and focus more on the needs of their children rather than on instructional objectives (Barack, 2020; Tate, 2020). These adults were seeking out answers, on their own, to the questions that were most relevant to them. This self-directed knowledge journey is known as heutagogy. We also saw reports of children pursuing interests such as baking, self-directed science experiments using household materials, and other characteristics of student-centered learning. This is also an example of heutagogy. Each of these examples showed the potential for a self-directed approach to learning. While many would have likely provided more guidance, more direction (or a self-regulated approach), we saw that many were able to adapt to a more learner-centered approach where they sought the sources of information, learned and then applied what they had learned to their new circumstances. This emergent approach is heutagogy.

\section{Background}

The term heutagogy, sometimes referred to as self-determined learning, was coined by Hase and Kenyon (2000) as an instructional approach that emphasizes self-determination in learners. In heutagogy, instructors serve as the compass for learners in their learning journey (Hase, 2009; Hase \& Kenyon, 2007). Heutagogy is not a learning theory such as constructivism or behaviorism, but instead a learner-centered instructional strategy or approach. Heutagogy recognizes learners' unique experiences and attempts to integrate those into the learning process (Carpenter \& Green, 2017). This approach arose from what Hase (2009) identified as deficiencies within the educational system, specifically the need 
to present instruction in a nonlinear way that allows for greater application to the world in which we live.

\section{Purpose}

The purpose of this systematic review was to provide a comprehensive review of peerreviewed articles between 2000 and 2019 that applied heutagogy to educational contexts, with a focus on application and implication for online learning contexts. The overarching question of interest was how the heutagogical approach can be applied in online learning contexts. To answer this, this review asked the following research questions:

(1) What are the assumptions and premises of heutagogy?

(2) What educational contexts have adapted heutagogical approaches?

\section{Method}

A systematic review was conducted to identify peer-review articles that answered the research questions (Arksey \& O'Malley, 2005). The review was guided by PRISMA principles (Liberati et al., 2009), and the procedure is shown in Figure 1.

\section{Initial search}

The initial search began using the ERIC, Academic Search Complete, and Education Source databases. The search term used in all three databases was "heutagogy" and Boolean

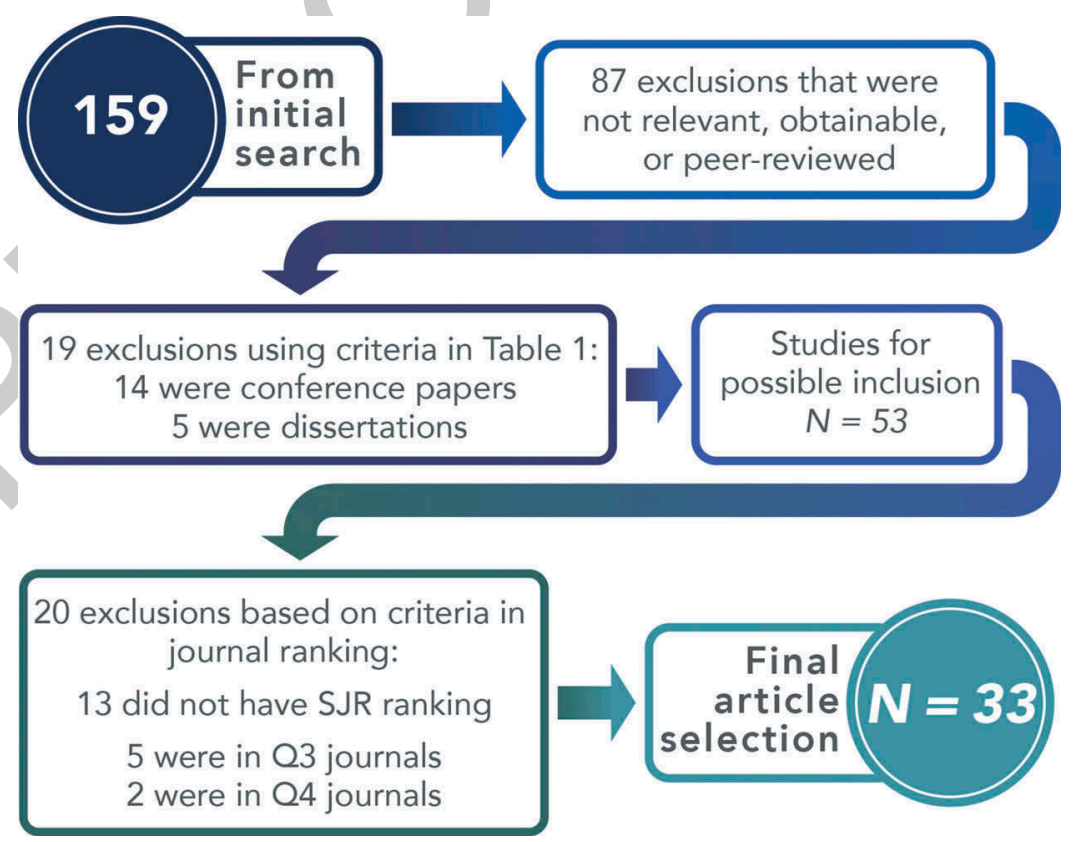

Figure 1. Article selection process. 
operators were added to search for additional terms, such as "heutagogy" AND "online learning."

\section{Study selection}

The date range was 2000-2019 to trace from the origins of heutagogy to the present day. These initial searches yielded 159 results. The same search terms were used in Google Scholar and yielded 2220 results. After removing duplicates, unobtainable, irrelevant, or not peer-reviewed results, 72 articles remained.

\section{Inclusion and exclusion criteria}

The 72 records were analyzed based on the inclusion and exclusion criteria in Table 1. Included records had to match all the inclusion criteria and none of the exclusion criteria. The records were reviewed, and additional exclusions were made, consisting of 14 conference papers and five dissertations. After this step, 53 articles remained.

To ensure high quality articles were used in this review, journal rankings from SCImago were consulted (https://www.scimagojr.com/journalrank.php). SCImago calculates their rankings using information in the Scopus database. The scientific journal ranking (SJR) score indicates a journal's average number of weighted citations. In addition to the $\mathrm{H}$ index (a measure of productivity and impact for authors and journals) and SJR score, SCImago also provides the thematic category of the journal according to Scopus Classification. While this list of journals is not exhaustive, it provided a mechanism through which to apply a consistent and rigorous standard to the journals. After the 53 articles were identified, an analysis was conducted on the journals using the SCImago Journal and Country rankings, and only articles published in journals ranked as either quartile 1 (Q1) or quartile 2 (Q2) were included. This final filtering resulted in the 33 articles selected for review. More than half of the articles (18 of 33) were in education-themed journals and were in Q1-ranked journals. A summary of the thematic categories and quartile breakdown is provided in Table 2.

\section{Synthesis}

The results of the synthesis of the 33 articles are discussed in the following sections. In addition to the 33 peer-reviewed articles, additional works, including book chapters and

Table 1. Inclusion and exclusion criteria.

\begin{tabular}{lr}
\hline Inclusion criteria & Exclusion criteria \\
\hline Article was peer-reviewed & $\begin{array}{c}\text { Result was book chapter, conference proceeding, dissertation, } \\
\text { or not a peer-reviewed source } \\
\text { Article appeared in a journal that did not have an SJR score }\end{array}$ \\
$\begin{array}{l}\text { Article used the heutagogical approach in a higher } \\
\text { education context }\end{array}$ & \\
$\begin{array}{c}\text { Article published in English-language academic } \\
\text { journal between 2000 and 2019 }\end{array}$ \\
$\begin{array}{l}\text { Article appeared in a journal ranked in either Q1 or } \\
\text { Q2 }^{\text {a }}\end{array}$ \\
\hline
\end{tabular}

${ }^{a}$ According to SCImago Journal and Country rankings (https://www.scimagojr.com/journalrank.php) 
Table 2. Reviewed articles by thematic category and quartile.

\begin{tabular}{lcc}
\hline & \multicolumn{2}{c}{$\begin{array}{c}\text { Number of articles by } \\
\text { quartile }\end{array}$} \\
\cline { 2 - 3 } Thematic category & Q1 & Q2 \\
\hline Education & 16 & 2 \\
Library and information sciences & 1 & 0 \\
Computer science (miscellaneous) & 1 & 1 \\
Computer science applications & 0 & 4 \\
Business, management, and accounting & 0 & 3 \\
Computer networks and communications & 0 & 2 \\
Engineering (miscellaneous) & 0 & 1 \\
Communication & 0 & 1 \\
\hline
\end{tabular}

other peer-reviewed articles, were reviewed to create a complete picture of heutagogy. These records provided context, such as the seminal texts for capability and double-loop learning, two core elements of heutagogy.

\section{Results and discussion}

\section{Research question 1: What are the assumptions and premises of heutagogy?}

The first research question focussed on the assumptions and premises of heutagogy. The discussion begins with an explanation of heutagogy as an emergent instructional approach, explores the role and applications of technology, then discusses the roles of humanism and constructivism in heutagogy, and concludes with an explanation of the pedagogy-andragogy-heutagogy continuum (Blaschke, 2012, 2019; Canning, 2010). A summary of the reviewed articles by theme appears in Table 3.

\section{Emergent instructional approach}

Heutagogy focusses not only on knowledge acquisition but also skill development (Bhoyrub et al., 2010; Carpenter \& Green, 2017). One of the foundational premises of heutagogy is a concept called learner agency. With learner agency, the learner is empowered to take control over their learning by determining what and how they learn as well as how they are assessed (Blaschke, 2018; Blaschke \& Hase, 2015). It is through this approach that learners can discover how they can best meet their learning objectives (Blaschke \& Hase, 2015; Canning, 2010). This agency better prepares them to handle the complex

Table 3. Themes and review articles for research question 1.

\begin{tabular}{lc}
\hline Theme & Review articles \\
\hline $\begin{array}{l}\text { Emergent instructional } \\
\text { approach }\end{array}$ & Abraham \& Komattil, 2017; Agonács et al., 2019; Ashton \& Elliott, 2007; Bhoyrub et al., \\
& 2010; Brown \& Mbati, 2015; Canning, 2010; Carpenter \& Green, 2017; Cochrane \& \\
Role of technology & Rhodes, 2013 \\
& Abraham \& Komattil, 2017; Ashton \& Elliott, 2007; Beaven et al., 2014; Blaschke, 2012; \\
Bumanism and constructivism \& Mbati, 2015; Cook \& Gregory, 2018; Narayan et al., 2019 & Abraham \& Komattil, 2017; Ashton \& Elliott, 2007; Blaschke, 2012; Canning, 2010; \\
& Carpenter \& Green, 2017; Jones et al., 2019; Kanwar et al., 2013; Links, 2018 \\
Pedagogy-andragogy- & Abraham \& Komattil, 2017; Agonács \& Matos, 2019; Ashton \& Newman, 2006; Beaven \\
heutagogy continuum & et al., 2014; Blaschke, 2012; Canning, 2010; Canning \& Callan, 2010; Carpenter \& \\
& Green, 2017; Haworth, 2016; Jones et al., 2019; Kanwar et al., 2013; Links, 2018 \\
\hline
\end{tabular}


nature of the workplace (Abraham \& Komattil, 2017; Blaschke, 2018, 2019; Blaschke \& Hase, 2015; Brown \& Mbati, 2015; Carpenter \& Green, 2017; Hase, 2009).

Heutagogy is not time bound, which lends more flexibility to the learner and lets them further engage with their learning. A key benefit of this flexibility is how it can support multiple learning preferences within the same classroom. Ashton and Elliott (2007) argued that the requirements for learners to master content in specific areas may be an antiquated approach to instruction. In a classroom using heutagogical principles, learning will be geared to the specific student instead of a one-size-fits-all instructional model. Hase (2009) posited that the role of questions is a key premise for heutagogy. Learners question their own thinking and must seek out answers that modify and resolve their thinking.

Heutagogy can provide learner and facilitator benefits. Utilizing a heutagogical approach can result in an environment in which learners are more engaged and spend more time in the learning process (Hase \& Kenyon, 2007). This leads to a more acute understanding of content. Learners are given agency to determine how and what they learn, creating a sense of buy-in resulting in more intrinsic motivation (Agonács et al., 2020; Blaschke, 2018, 2019; Canning, 2010; Hase \& Kenyon, 2007; Pal \& Roy, 2019). Learners develop skills that enhance their active learner capabilities because heutagogy focusses on discovering how learners best prefer to learn and fostering that specific method (Blaschke \& Hase, 2015; Canning, 2010; Carpenter \& Green, 2017; Durkin-Boyle, 2017; Stoszkowski \& McCarthy, 2018). This newfound success with the personal learning process creates higher levels of self-efficacy in learners (Brown \& Mbati, 2015; Carpenter \& Green, 2017; Pal \& Roy, 2019).

Moreover, the benefits are not solely for learners but for facilitators, too. Heutagogy creates opportunities for instructional facilitators to develop a more direct relationship with learners while guiding them toward their learning goals. Facilitators will likely find that they are learning alongside their students and will explore new approaches to instruction. The learners, in turn, increase their capability to learn and also have opportunities to accomplish more academic goals (Blaschke, 2018; Hase \& Kenyon, 2013).

\section{Role of technology}

Technology and heutagogy are intertwined in a symbiotic relationship. Blaschke (2013) asserted that heutagogy could not exist if not for Web 2.0 technologies, as these advances have simplified the process through which learners connect and collaborate in various contexts. A growing proportion of learning occurs outside formal educational settings, where information and learning opportunities are mediated by technology (Beaven et al., 2014; Brown \& Mbati, 2015). Recent advances with technology have created new opportunities for learners to have more control over how and where their learning takes place, in turn making learning a continuous process (Cook \& Gregory, 2018). This aligns well with heutagogical principles and fosters the type of self-determined learning essential to this emerging learning approach.

Web 2.0 technologies. Technology, such as smartphones and web-based applications, has made it easier for students to become content creators. The resulting content can be used to integrate heutagogical principles into instruction, particularly online learning (Blaschke, 2018; Cochrane \& Rhodes, 2013; Gregory \& Bannister-Tyrrell, 2017). The e-learning environment incorporates collaboration, interaction, and engagement, which are key reasons why 
heutagogy has been applied to this online environment (Blaschke, 2019; Hase, 2009; Pal \& Roy, 2019). Within this learning context, instructors can use a blended approach that incorporates multimedia and takes advantage of heutagogical principles (Ashton \& Elliott, 2007). Heutagogy supports the iterative nature of learning using collaborative approaches to assessments, feedback, and review (Hase \& Kenyon, 2013).

Social media. The collaborative and learner-centered nature of Web 2.0 tools, such as social media, blogs and wikis, creates opportunities that nurture the resolution and selfdriven nature of heutagogical learning (Blaschke, 2012, 2013, 2018, 2019; Filipe \& Mack, 2019; Nadelson et al., 2017). Through the use of social media, instructors are able to provide scaffolding and simultaneously support engagement and learner autonomy (Abraham \& Komattil, 2017). An example is using Twitter to handle back-channel communications during a live event, such as a class or a conference event (Moore, 2014). Students can post questions in real time and receive responses from their classmates; it also creates an archive of time-stamped communication during a live event and can be a helpful resource for review of course content. Another benefit of social media is that it enables learners to determine when and how they engage with the tool and supports their ability to self-determine their level of involvement and participation (Narayan et al., 2019). Through the integration of social media, instructors can enable learners to create authentic learning communities tailored to their specific needs (Brown \& Mbati, 2015).

Mobile learning. More broadly, mobile learning is a concept that has direct ties to heutagogical principles. With mobile learning, there is more flexibility in when, how, and where learning will take place-all advantages of open and distance learning environments (Brown \& Mbati, 2015; Narayan et al., 2019). Mobile devices empower learners to become content creators, enabling instruction to be more flexible and adaptable to specific student needs and interests (Narayan et al., 2019). In online learning, this can be a powerful advantage. The COVID-19 global pandemic has demonstrated just how connected we can stay through technology as students participate in class-based discussions using laptops or smartphones while in disparate locations (Deming, 2020; Hill, 2020; Noguchi, 2020; Reynolds, 2020). The instructor can foster engagement and interaction by putting students into breakout rooms or leveraging real-time collaboration tools such as Google Docs or Google Slides.

Technology can also be used to create virtual learning environments, known as augmented, virtual, or mixed reality. This further encourages flexible and contextspecific instruction. An example of this is having students take a virtual museum tour using their phone or laptop, moving through the museum at their own pace and identifying what is most interesting to them (Cook \& Gregory, 2018). Context-aware technologies make it possible to augment the learner's environment with relevant and supportive information and services (Brown \& Mbati, 2015).

\section{Humanism and constructivism}

Humanism and constructivism underpin heutagogy. From the humanistic perspective, heutagogy sees the learner as central to the educational process. Students can empower themselves by taking control over their learning and developing their own learning philosophy (Canning, 2010). The resulting effect can be a transformational experience (Jones et al., 2019). The theory of heutagogy contains principles that may be a response to developments within higher education (Durkin-Boyle, 2017; Gregory et al., 2018). In online 
contexts, we see this when students have options for completing course content within a learning management system (LMS) or when they enroll in a massive open online course (MOOC) that aligns to their personal interests.

From the constructivist viewpoint, heutagogy takes the notion that people construct their version of reality by using past and current knowledge and experiences (Carpenter \& Green, 2017). Recent advances in neurology have given us a better understanding of how the human brain functions and by which means learning occurs on a neurological level. The new ability to link brain activity to learning environment presents opportunities to develop instruction that is more tailored to learners (Blaschke \& Hase, 2015; Hase \& Kenyon, 2013). Hase and Kenyon (2013) pointed to neurological studies on how patterns are used to build new schemas in memory and learning processes. This linkage to lived experiences aligns with the constructivist approach built on the concept of learners using experiences to frame and shape their learning environment. There is not one single approach that will work for every learner as human brains are unique, bringing into question how effective current didactic and instructor-centered learning environments are. While students manage the competing priorities in their lives, the use of flexible and blended heutagogical models of knowledge-creating enables them to deal with the real issues of work, family, and study while developing the attributes needed for today's world (Abraham \& Komattil, 2017; Ashton \& Elliott, 2007).

Hase and Kenyon (2013) incorporated the work of several scholars into heutagogy, including the concept of capability (Stephenson, 1998; Stephenson \& Weil, 1992) and double-loop learning (Argyris \& Schon, 1978). Learning, according to Hase and Kenyon (2013), can be understood as occurring at two distinct levels-competency and deeper learning. In single-loop learning, a student identifies a problem, takes an action which produces a reaction, and then begins a new issue. The competency level consists of the acquisition of knowledge and skills; this is the level that pedagogy and andragogy describe (Hase, 2009; Hase \& Kenyon, 2000; Kanwar et al., 2013). However, Abraham and Komattil (2017) cautioned that learners should not stop at competency and should instead move to demonstration of mastery of the content.

In double-loop learning, there is self-reflection on the learning process (Eberle, 2013; Kanwar et al., 2013). Once competencies have been developed, learners are then able to move toward the demonstration of capability, which is the application of knowledge in new situations (Blaschke, 2012, 2014; Links, 2018; Pal \& Roy, 2019). It is for this reason that competencies are the "building blocks of learning" (Hase \& Kenyon, 2013, p. 25). This type of deeper learning developed through double-loop learning can make learners more aware of their preferred learning style (Blaschke, 2012). The focus on both competency and capability is what makes heutagogy apt at addressing the needs of adult learners in complex and changing work environments (Bhoyrub et al., 2010; Blaschke, 2012). Wikis, blogs, and discussion forums are tools that instructors can use to support self-reflection within online learning environments. The advancement from single-loop learning to double-loop learning, the integration of capability, and the progress from pedagogy to heutagogy are some of the important features of lifelong learning (Hase, 2009; Kanwar et al., 2013; Pal \& Roy, 2019).

One way to understand the differences between competency and capability is to consider the work of a firefighter. Would one want a first responder to a fire to have never actually used a water hose before? Firefighting training programs build core skills, 
but then they must learn how to adapt and apply those competencies to different situations. This is where capability develops-which is why they are often assigned to scenario-based training exercises that force them to apply their knowledge and experience the consequences of poor decisions. Through these exercises, they better learn how to handle similar or more intricate situations.

\section{Pedagogy-andragogy-heutagogy continuum}

Heutagogy should not be seen as replacing, or better than, pedagogy and andragogy, but instead as a shift in the instructional approach and an extension of pedagogy and andragogy (Hase \& Kenyon, 2007; Jones et al., 2019). Some have argued that we should not use pedagogy as an instructional framework for developing adult learners (Carpenter $\&$ Green, 2017). Andragogy (Knowles et al., 2015) has been the preeminent learning theory for adult learners since the 1970s, but it may not fully support learner-centered learning environments (Carpenter \& Green, 2017; Eachempati et al., 2017; Hase, 2009; Hase \& Kenyon, 2007). There are elements of both pedagogy and andragogy in heutagogy. One of the key differences is the shift from self-directedness in andragogy to selfdeterminedness in heutagogy, and thus the change from a teacher-centered to a learnercentered instructional environment (Ashton \& Newman, 2006; Naqvi \& Parvez, 2019; Speight, 2018). Even though andragogy acknowledges self-directedness in learners, there is still a considerable instructor influence on pathways and instructional sequencing (Abraham \& Komattil, 2017). Where andragogy is presented as a linear perspective on learning (Knowles et al., 2015), heutagogy employs double-loop learning (Hase, 2009; Kanwar et al., 2013). Links (2018) further explained the difference in terms of flow of information and explained that andragogy is content driven while heutagogy takes a more process-directed approach. With more adult learners seeking postgraduate degrees and credentialing (Barbosa De Almeida Cabral et al., 2017; Moore \& Fodrey, 2018; Shah, 2018), a learning approach that supports their unique needs is essential. In many ways, a heutagogical approach can better support the diversity of learners in these open and online learning environments.

Blaschke (2019) offered two views of the heutagogical approach. The first perspective is that the school system suppresses the ability of younger learners to demonstrate selfdetermination (Hase, 2009; Hase \& Kenyon, 2000, 2007, 2013); and, in the second perspective, learners are in a continuum from pedagogy to andragogy to heutagogy (Beaven et al., 2014; Blaschke, 2012, 2019; Canning, 2010; Kanwar et al., 2013; Pal \& Roy, 2019). The focus of the second perspective is the level of learner autonomy (Figure 2). As the learner moves from pedagogy to heutagogy, there is an increase in learner maturity and autonomy and an associated decrease in course structure and instructor control (Blaschke, 2012, 2019; Canning, 2010; Kanwar et al., 2013). To put this continuum into the context of online learning, the structure of an LMS will be used to demonstrate each stage on the continuum.

Pedagogy. Starting from the far left of the continuum is pedagogy. At this stage, there are the lowest levels of learner autonomy. This type of instruction will have higher levels of instructor control and the face-to-face delivery methods align mostly to sage on the stage or chalk and talk (Blaschke, 2019). The course websites within the LMS for courses using this instructional approach will be highly structured. These courses will have a linear design with a heavy requirement for instructor guidance to move learners through the 


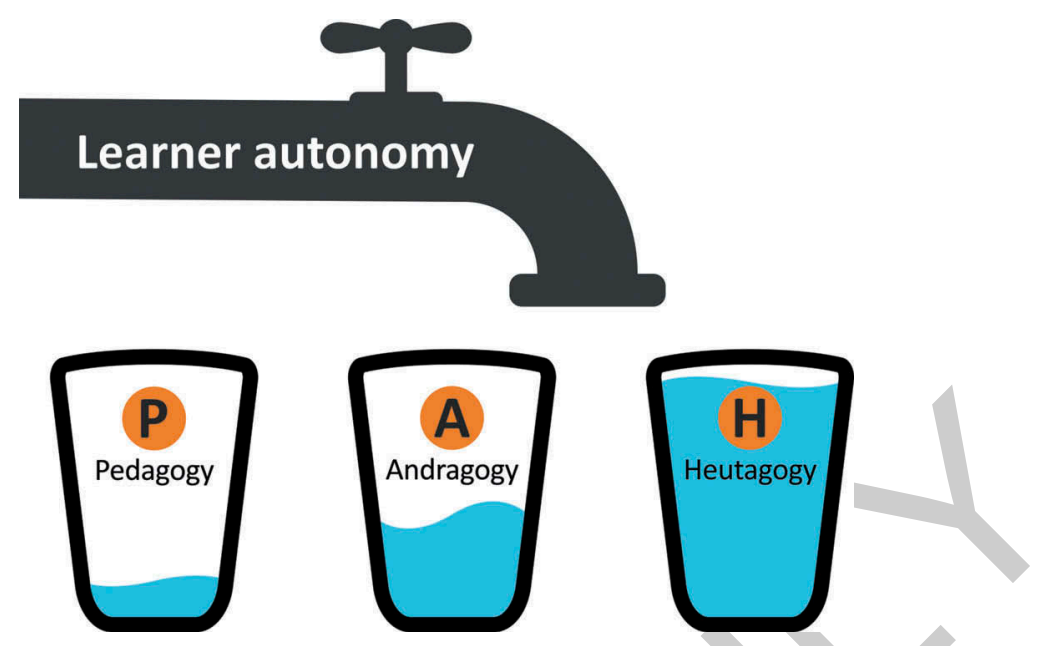

Figure 2. Levels of learner autonomy (adapted from Blaschke, 2012, p. 60, \& Canning, 2010, p. 63).

curriculum (Blaschke, 2019; Canning \& Callan, 2010). There are few opportunities for learners to deviate from the prescribed structure and activities of the course. The focus here is on the transfer and acquisition of knowledge (Blaschke, 2019).

Andragogy. Moving from pedagogy to andragogy will continue to situate learners at the single-loop learning stage while further developing their competency (Hase \& Kenyon, 2000). Instructors are still a strong influence at this stage but will be transitioning to more of a facilitator role, focussing on guiding learners through the achievement of learning objectives (Abraham \& Komattil, 2017). The course structure will be more open in the LMS. A common example would be the releasing of all the instructional content modules or units at the start of the semester. While learners still have instructor-set deadlines, they could move ahead if needed. This allows for more autonomy and selfdirected learning (Canning \& Callan, 2010; Kanwar et al., 2013). Another example is how discussion forum assignments are structured. A common approach would be to set a deadline to make initial posts and then a date several days later to complete replies (Moore, 2016). This provides students flexibility in when they make initial and reply to posts but instructors still have a level of control over how the assignments are completed (Jones et al., 2019).

Heutagogy. At the third and final phase of heutagogy, the learners have fully grasped control of their learning and the instructor has less direct involvement (Blaschke, 2019; Kanwar et al., 2013; Pal \& Roy, 2019). At this end of the spectrum, the learner autonomy is at its highest and double-loop learning (Argyris \& Schon, 1978) will be fully demonstrated. Using the LMS example, this course will resemble more of a self-paced course. There will be few, if any, actual deadlines. Instead, the focus will be on deliverables, and students will move through the content in the sequence of their choosing to develop the skills to complete the deliverables. The deliverables can include final activities such as writing a final paper or passing a final exam. The capability development that will be evident at this stage is the key distinction between andragogy and heutagogy (Agonács \& Matos, 2019). Learners at this stage will transition from self-directed to self-determined learning (Blaschke, 2019) and demonstrate high levels of autonomy and maturity. But as autonomy 
increases, so too does the necessity for higher levels of self-reflection and self-assessment (Haworth, 2016; Links, 2018). This can be a challenge for learners as they may be more comfortable when they have an instructor to provide feedback and prompts for reflection at regular intervals (Links, 2018).

\section{Research question 2: What are learning environments and contexts?}

For the second research question, the review focussed on the types of learning environments and contexts that support heutagogical approaches to learning. The emerging themes were workplace environments, including informal online learning; higher education; medical education; professional development; and MOOCs. The themes and review articles are summarized in Table 4.

\section{Workplace environments}

The dynamic and evolving nature of the workplace makes it a particularly well-suited environment for the heutagogical approach (Ashton \& Newman, 2006; Blaschke, 2019; Blaschke \& Hase, 2016; Hase, 2009). Hase (2009) pointed to the need for workers to not only identify skill gaps but also seek solutions to fill these gaps as reasons why heutagogy can work well in the workplace. The modern workplace places a premium on workers that can demonstrate capability instead of mere competence. In the context of higher education, the workplace takes the context of professional or personal development. In recognition of the type of learning that occurs outside of the classroom, there has been growing interest in the use of prior learning assessment (Blaschke \& Hase, 2015; Durkin-Boyle, 2017). Prior learning assessment gives learners the ability to have their experience and skills recognized through academic credit (Blaschke \& Hase, 2015).

We engage in nearly constant forms of informal online learning, defined as learning that happens when accessing the Internet (Holland, 2019). While watching a television show, someone may look up an actor to see what other shows they have appeared in-this is an example of informal online learning. It happens so frequently we often do not consider it learning or even notice that we are doing it. One of the indicators of informal online learning is the role of questions-most learning begins with a question (Holland, 2019). This makes the subsequent searching for information a self-determined learner-centered act. One example is the use of Wikipedia, which is a learner-generated repository of information that is curated by volunteers in a public space (Holland, 2019).

Table 4. Themes and review articles for research question 2.

\begin{tabular}{|c|c|}
\hline Theme & Review articles \\
\hline Workplace & Ashton \& Newman, 2006; Blaschke, 2012; Holland, 2019 \\
\hline Higher education & $\begin{array}{l}\text { Canning \& Callan, 2010; Cochrane \& Rhodes, 2013; Cochrane et al., 2013; Faherty, 2015; Green \& } \\
\text { Schlairet, 2017; Jones et al., 2014; Jones et al., 2019; Mulrennan, 2018; Narayan et al., } 2019\end{array}$ \\
\hline ion & Green \& Huntington, 2017; Green \& Schlairet, 2017; Links, 2018 \\
\hline $\begin{array}{l}\text { Professional } \\
\text { development }\end{array}$ & $\begin{array}{l}\text { Bali \& Caines, 2018; Carpenter \& Green, 2017; Carpenter \& Linton, 2016; Cochrane \& Narayan, } \\
\text { 2013; Kubalíková \& Kacian, } 2016\end{array}$ \\
\hline MOOCs & $\begin{array}{l}\text { Agonács \& Matos, 2019; Agonács et al., 2019; Anders, 2015; Bali \& Caines, 2018; Beaven et al., } \\
2014\end{array}$ \\
\hline
\end{tabular}




\section{Higher education}

Heutagogy, often explained in the context of adult education, has widespread educational applications in a variety of contexts (Blaschke, 2012; Green \& Schlairet, 2017; Hase, 2009; Hase \& Kenyon, 2013). In their study of higher education institutions in the United Kingdom, Canning and Callan (2010) linked the demonstration of capacity and capability to the application of heutagogical principles. Heutagogy has been used for course redesigns in higher education courses where heutagogical principles were used to shift the focus from instructor-centered to a more student centered approach. The integration of heutagogical principles has guided course redesigns in journalism (Cochrane et al., 2013; Mulrennan, 2018; Narayan et al., 2019), enterprise education (Faherty, 2015; Jones, 2016; Jones et al., 2014; Jones et al., 2019), and architecture education (Cochrane \& Rhodes, 2013).

For these course redesigns, technology was used to shift from a more pedagogical to heutagogical approach. The technology enabled students to take a more active role in how they created, consumed, and demonstrated their mastery of the content. It also gave more flexibility for how, where, and when learning took place. In a journalism course redesign, Mulrennan (2018) focussed on ways to reconceptualize assessments by providing more opportunities for student-directed learning and an increased utilization of social media tools. These tools helped create stronger connections between theory and practice-a key component of a heutagogical approach. Mobile learning tools were also used to facilitate more learner-generated content within an enterprise education course redesign (Cochrane $\&$ Rhodes, 2013). For these redesigns, the technology integration helped create more authentic learning environments (Cochrane \& Rhodes, 2013; Faherty, 2015; Jones et al., 2019; Mulrennan, 2018; Narayan et al., 2019)

\section{Medical education}

Another context that has seen success with applying heutagogical approaches is medical education. Healthcare professionals must stay current on best practices and be able to accurately apply this knowledge to unique situations (Green \& Huntington, 2017). This need to adapt to dynamic work conditions is supported through heutagogical principles. As highlighted by Green and Schlairet (2017), clinicians must also have experience with responding to various medical situations. A way to meet these needs is through a flipped classroom approach, which provides opportunities to master the content and then apply it in authentic environments. This approach has been useful particularly with pharmacy and nursing students (Green \& Schlairet, 2017). In providing this flipped instructional approach, clinicians have opportunities to take a more active role in how they manage their own learning and have the flexibility to be self-directed (Green \& Schlairet, 2017). Clinicians need ongoing education as there are ever-evolving medical situations. Ongoing medical education lends itself well to a more self-determined approach as research and learning will be driven by specific feedback, problems, or interests (Links, 2018). Thus, it is critical that clinicians demonstrate capability versus competency (Links, 2018). This emphasis fits well with the move from a rigid curriculum to a flexible approach to learning that evolves as the learner's scope of practices changes throughout the life cycle of a clinician.

\section{Professional development}

In the context of professional development, there is a tension between institutions dictating what needs to be learned and faculty having control over how and what they 
learn (Bali \& Caines, 2018; Carpenter \& Green, 2017). This one-size-fits-all approach to professional development can create inequalities as the development needs of the marginalized are not being addressed (Bali \& Caines, 2018). The result can be a lack of innovation and creativity, particularly within the role of instructional delivery methods. And the environment is critical for professional development. As Kubalíková and Kacian (2016) highlighted, in a restricted county, such as Slovakia, there is not a receptive environment to the heutagogic approach to professional development. In their quartercentury review of professional development in the post-communist era of Slovakia, they found that many of the restrictions from the communist regime still existed within the educational system. This centralized approach to education runs counter to the necessary structure for a heutagogical approach.

To address these inequalities and create an environment that is supportive of the heutagogical approach, educators have a couple of options. The first is to make use of technology, in particular social media, to make professional development more open (Bali \& Caines, 2018). By taking advantage of social media, educators can take more control over their learning and demonstrate the self-directedness that is a key part of heutagogy (Bali \& Caines, 2018; Carpenter \& Green, 2017). Another way that educators can take more control over their professional development is by participating in unconferences, known as Edcamps (Carpenter \& Green, 2017; Carpenter \& Linton, 2016, 2018). These unconferences are free and have participants determine the session topics, usually through an opening brainstorming session. The structure of unconferences links to heutagogical principles as the sessions will be learner-driven and focussed on the topics most applicable to the attendees. A synergy is formed around specific topics, which allows for indepth conversation and networking that often extend beyond that particular session (Carpenter \& Green, 2017).

Institutions benefit from providing a more open approach to professional development (Bali \& Caines, 2018). For one, educators will be more motivated to explore items that are of interest. Another benefit was found by a study conducted by (Cochrane \& Narayan, 2013). In their study, heutagogical principles were used to offer a professional development course. After the course, the researchers found that many participants returned to their home institutions and developed their own courses that focussed on heutagogical principles. This enabled more faculty to benefit from this approach.

\section{MOOCs}

MOOCs offer an ideal environment for self-determined learners as enrollments in courses are driven by learner interest (Beaven et al., 2014). The nonlinear nature of MOOCs makes them ideal for heutagogical approaches (Agonács \& Matos, 2019; Agonács et al., 2020; Anders, 2015; Beaven et al., 2014). There are two primary types of MOOCs-cMOOCs and xMOOCs (Anders, 2015; Beaven et al., 2014; Bonk et al., 2017); and within these two types, there are three categories - network-based, task-based, and content-based (Lane, 2012, as cited in Beaven et al., 2014). These categories align with participatory levels and the pedagogy-andragogy-heutagogy continuum as learner autonomy increases and instructor control decreases as the course approach moves from content-based to task-based to network-based (Beaven et al., 2014). An xMOOC will follow the traditional instructor-driven structure and will be content-based (Beaven et al., 2014; Bonk et al., 2017: Moore et al, 2019). Conversely, cMOOCs, or connectivist 
MOOCs, are closely aligned with heutagogical principles (Anders, 2015; Beaven et al., 2014). Anders (2015) further differentiated between the two types, by emphasizing the goal of cMOOCs as being an interest in learner-generated content and a greater focus on collaborative learning. Although an $\mathrm{XMOOC}$ will have an active facilitator who will provide instructional content, a cMOOC will integrate social media and collaborative content approaches to empower learners to provide the content and the associated learning pathways through a network-based approach to learning (Anders, 2015; Bali \& Caines, 2018).

As MOOCs have evolved, there have been hybrid designs which are attempts to give even more flexibility and control to learners. One of these hybrid designs is known as a dual pathway MOOC, in which the participants do not have to select one instructional approach and are able to seamlessly move between more instructor-driven and studentdriven content (Bali \& Caines, 2018). The University of Texas at Arlington has a dualpathway MOOC "Data, Analytics and Learning," delivered on the edX platform (Bali \& Caines, 2018).

\section{Critiques and challenges}

Heutagogy is not without its critiques and challenges. The most glaring critique is the lack of empirical evidence regarding the application of the approach (Agonács \& Matos, 2019). This is one reason that heutagogy is not an established learning theory (Bhoyrub et al., 2010). In their systematic review of empirical articles applying heutagogy, Agonács and Matos (2019) discovered that researchers were focussed on understanding certain phenomena related to heutagogy rather than explaining and predicting them-resulting in mostly qualitative studies. In order to address this lack of empirical reason, there is a need for additional studies, particularly situated in non-formal learning environments and in online environments (Agonács \& Matos, 2019; Blaschke, 2012). In addition, there are also challenges to the implementation of heutagogical approaches, specifically with assessments and institutional policies.

\section{Assessment}

The first challenge is with the assessment component. In a traditional classroom, the instructor develops, delivers, and grades activities and learning within the classroom. However, in a heutagogical learning environment, the learner identifies the method through which they want to receive assessments and take active steps in developing these assessments (Blaschke, 2019; Hase \& Kenyon, 2013). This can be a challenge both for the instructor (tasked with creating an environment that allows for formative assessment) and the learner (tasked with taking ownership over their own assessment) (Blaschke, 2019; Hase, 2009; Pal \& Roy, 2019).

One way to mitigate the assessment challenge is through leveraging e-learning technologies, which could provide more evidence of the effectiveness of online learning for heutagogical approaches (Hase, 2009). Although some will argue against selfdetermined learning by pointing to the extra time that it takes to implement, Hase and Kenyon (2013) countered that the benefits to learners far outweigh any amount of time taken to create the learning environment. The process of negotiating assessments can 
lead to more motivated learners as they are able to take more ownership over their learning (Hase, 2009).

\section{Institutional policies}

The shifting of evaluation responsibility from the instructor to the learner is likely the element that gives the most concern to administrators when considering whether to approve this type of instructional approach. In heutagogy, learning is not conceptualized as a linear path, and it is thus important that the learner can review their progress continually and apply the knowledge to practice (Blaschke, 2013, 2019; Eachempati et al., 2017; Hase, 2009; Pal \& Roy, 2019). Institutions are reliant on accreditation and permit these entities to dictate what learning looks like, how it is measured, and what is essential (Blaschke \& Hase, 2015). It has been argued that it is actually the constraints of passing tests and standardized curricula that hamper the ability of learners to question and be self-determined learners (Blaschke \& Hase, 2015; Hase, 2009). For these reasons, heutagogy does not squarely fit into existing educational structures (Blaschke, 2012). The negotiated assessment that gives learners the ability to define learning in their own terms can further present challenges for receiving curriculum approval and accreditation. When giving learners power over assessment, there are concerns that it makes it difficult to measure learning within the classroom.

\section{Conclusion}

This systematic review synthesized peer-reviewed articles to explore the premise and contexts of heutagogy and how these apply to online learning environments. The focus on peer-reviewed articles highlighted the most significant limitation of heutagogy. As this review and others (e.g., Agonács \& Matos, 2019) have shown, there is a lack of empirical evidence to support the heutagogical approach. This lack of empirical research is why heutagogy will remain an emerging instructional approach instead of becoming a learning theory, such as constructivism. The nature of how heutagogy was conceptualized-as an extension of pedagogy and andragogy - also limits the empirical impact as it is difficult to be able to pinpoint where andragogy ended and heutagogy began. This is not necessarily a bad thing and speaks to the flexibility and applicability of heutagogy. It demonstrates the ability of heutagogy to be applied and implemented in a variety of contexts, both in formal and informal learning environments.

Although heutagogy presents opportunities to leverage the Web 2.0 technologies and affordances of distance education, it is not without challenges, particularly around accreditation, institutional policies, and implementation. These challenges can be roadblocks for heutagogy being fully implemented within traditional educational settings. But there is a place for heutagogy in the overall education landscape because so much of our learning occurs outside of traditional and formal learning environments (Beaven et al., 2014; Brown \& Mbati, 2015). Instructors at all levels can explore opportunities to integrate heutagogical approaches into their current curriculum in ways that can foster and develop lifelong learning skills. An example can be revising the final course assignment to have more flexibility with topic and delivery selection and thus giving learners more autonomy in how they complete that final 
assignment. Subtle challenges to assignments such as this can enable instructional goals to be still met while still supporting the learner-centered approach that is foundational to heutagogy. As more and more education moves to online modalities, learners will need to learn how to be more autonomous in how they seek out but also apply and learn instructional context. As the needs of learners evolve, it is critical that education also evolves in the instructional approaches that are used. The heutagogical approach places a heavy emphasis on the learner's autonomy in a way that fosters the type of lifelong learning that is critical for success in the 21 st century and beyond.

Researchers should design empirical-based studies that seek to validate the heutagogical learning approach. To move in this direction, researchers could follow the example of how the community of inquiry framework (Col, Garrison et al., 2001) was validated. After identifying the three presences of the Col framework, an instrument to measure these presences was developed and validated by researchers. There has been extensive research where the Col instrument has been applied in various contexts, such as MOOCs (Kovanović et al., 2018) and online graduate programs (Kumar \& Ritzhaupt, 2014). Additionally, recent research has focussed on ways to revise and apply Col to new contexts including creating additional presences (Kozan \& Caskurlu, 2018). For heutagogy, the first step would be identifying the key elements and how those can be measurable and distinguishable from andragogy and pedagogy. This would require consensus on what heutagogy is versus what andragogy or pedagogy are. After reaching this consensus, researchers could then measure these elements and their associated influence on learner outcomes and knowledge transfer. The development of the heutagogy instrument would require a validation process that would enable researchers to test the survey in different instructional contexts and move heutagogy from an emerging learning approach to an empirically supported theory.

\section{Disclosure statement}

No potential conflict of interest was declared by the author.

\section{Notes on contributor}

Robert L. Moore is an assistant professor of instructional design and technology at Old Dominion University. His research focusses on developing participatory online learning environments and using learning analytics techniques to understand online learner engagement in MOOCs.

\section{ORCID}

Robert L. Moore (D) http://orcid.org/0000-0002-5645-9297

\section{References}

Abraham, R. R., \& Komattil, R. (2017). Heutagogic approach to developing capable learners. Medical Teacher, 39(3), 295-299. https://doi.org/10.1080/0142159X.2017.1270433 
Agonács, N., \& Matos, J. F. (2019). Heutagogy and self-determined learning: A review of the published literature on the application and implementation of the theory. Open Learning, 34(3), 223-240. https://doi.org/10.1080/0142159X.2017.1270433

Agonács, N., Matos, J. F., Bartalesi-Graf, D., \& O'Steen, D. N. (2020). Are you ready? Self-determined learning readiness of language MOOC learners. Education and Information Technologies, 25(2), 1161-1179. https://doi.org/10.1007/s10639-019-10017-1

Anders, A. (2015). Theories and applications of massive online open courses (MOOCs) : The case for hybrid design. The International Review of Research in Open and Distributed Learning, 16(6), 39-61. https://doi.org/10.19173/irrodl.v16i6.2185

Argyris, C., \& Schon, D. (1978). Organizational learning: A theory of action perspective. AddisonWesley.

Arksey, H., \& O'Malley, L. (2005). Scoping studies: towards a methodological framework. International Journal of Social Research Methodology, 8(1), 19-32. https://doi.org/10.1080/1364557032000119616

Ashton, J., \& Elliott, R. (2007). Juggling the balls—study, work, family and play: Student perspectives on flexible and blended heutagogy. European Early Childhood Education Research Journal, 15(2), 167-181. https://doi.org/10.1080/13502930701321378

Ashton, J., \& Newman, L. (2006). An unfinished symphony: 21st century teacher education using knowledge creating heutagogies. British Journal of Educational Technology, 37(6), 825-840. https://doi.org/10.1111/j.1467-8535.2006.00662.x

Bali, M., \& Caines, A. (2018). A call for promoting ownership, equity, and agency in faculty development via connected learning. International Journal of Educational Technology in Higher Education, 15(46), 1-24. https://doi.org/10.1186/s41239-018-0128-8

Barack, L. (2020, April 1). Remote instruction presents opportunity to empower self-directed learning skills. Education Dive. https://www.educationdive.com/news/remote-instruction-presentsopportunity-to-empower-self-directed-learning-s/575116/

Barbosa De Almeida Cabral, P., Riberiro Jorge, N., \& van Valkenburg, W. (2017). MicroMasters: The pursuit of the Holy Grail in online learning. In G. Ubachs \& L. Konings (Eds.), Proceedings of The Online, Open and Flexible Higher Education Conference (pp. 219-225). European Association of Distance Teaching Universities. https://www.narcis.nl/publication/RecordID/oai:tudelft.nl:uuid\% 3A47d74e35-856c-4f74-b48f-e8f07329652e

Beaven, T., Hauck, M., Comas-Quinn, A., Lewis, T., \& de los Arcos, B. (2014). MOOCs: Striking the right balance between facilitation and self-determination. MERLOT Journal of Online Learning and Teaching, 10(1), 31-43. https://jolt.merlot.org/vol10no1/beaven_0314.pdf

Bhoyrub, J., Hurley, J., Neilson, G. R., Ramsay, M., \& Smith, M. (2010). Heutagogy: An alternative practice based learning approach. Nurse Education in Practice, 10(6), 322-326. https://doi.org/ 10.1016/j.nepr.2010.05.001

Blaschke, L. M. (2012). Heutagogy and lifelong learning: A review of heutagogical practice and self-determined learning. The International Review of Research in Open and Distributed Learning, 13 (1), 56-71. https://doi.org/10.19173/irrodl.v13i1.1076

Blaschke, L. M. (2013). E-learning and self-determined learning skills. In S. Hase \& C. Kenyon (Eds.), Self-determined learning: Heutagogy in action (pp. 55-67). Bloomsbury.

Blaschke, L. M. (2014). Using social media to engage and develop the online learner in self-determined learning. Research in Learning Technology, 22, 1-23. https://doi.org/10.3402/rlt. v22.21635

Blaschke, L. M. (2018). Self-determined learning (heutagogy) and digital media creating integrated educational environments for developing lifelong learning skills. In D. Kergel, B. Heidkamp, P. Telleus, T. Rachwal, \& S. Nowakowski (Eds.), The digital turn in higher education (pp. 129-140). Springer. https://doi.org/10.1007/978-3-658-19925-8_10

Blaschke, L. M. (2019). The pedagogy-andragogy-heutagogy continuum and technology-supported personal learning environments. In I. Jung (Ed.), Open and distance education theory revisited: Implications for the digital era (pp. 75-84). Springer. https://doi.org/10.1007/978-981-13-7740-2_9

Blaschke, L. M., \& Hase, S. (2015). Heutagogy, technology, and lifelong learning for professional and part-time learners. In A. Dailey-Hebert \& K.S. Dennis (Eds.), Transformative perspectives and processes in higher education (pp. 75-94). Springer. https://doi.org/10.1007/978-3-319-09247-8_5. 
Blaschke, L. M., \& Hase, S. (2016). Heutagogy: A holistic framework for creating twenty-first-century self-determined learners. In B. Gros, Kinshuk, \& M. Maina (Eds.), The future of ubiquitous learning, lecture notes in educational technology (pp. 25-40). Springer. https://doi.org/10.1007/978-3-66247724-3_2

Bonk, C. J., Lee, M. M., Reeves, T. C., \& Reynolds, T. H. (2017). The emergence and design of massive open online courses (MOOCs). In R. A. Reiser \& J. V. Demsey (Eds.), Trends and issues in instructional design and technology (4th ed., pp. 250-258). Pearson.

Brenan, M. (2020, March 31). 42\% of parents worry COVID-19 will affect child's education. Gallup. https://news.gallup.com/poll/305819/parents-worry-covid-affect-child-education.aspx

Brown, T. H., \& Mbati, L. S. (2015). Mobile learning: Moving past the myths and embracing the opportunities. The International Review of Research in Open and Distributed Learning, 16(2), 115-135. https://doi.org/10.19173/irrodl.v16i2.2071

Canning, N. (2010). Playing with heutagogy: Exploring strategies to empower mature learners in higher education. Journal of Further and Higher Education, 34(1), 59-71. https://doi.org/10.1080/ 03098770903477102

Canning, N., \& Callan, S. (2010). Heutagogy: spirals of reflection to empower learners in higher education. Reflective Practice, 11(1), 71-82. https://doi.org/10.1080/14623940903500069

Carpenter, J. P., \& Green, T. D. (2017). Mobile instant messaging for professional learning: Educators' perspectives on and uses of Voxer. Teaching and Teacher Education, 68, 53-67. https://doi.org/ 10.1016/j.tate.2017.08.008

Carpenter, J. P., \& Linton, J. N. (2016). Edcamp unconferences: Educators' perspectives on an untraditional professional learning experience. Teaching and Teacher Education, 57, 97-108. https://doi.org/10.1016/j.tate.2016.03.004

Carpenter, J. P., \& Linton, J. N. (2018). Educators' perspectives on the impact of Edcamp unconference professional learning. Teaching and Teacher Education, 73, 56-69. https://doi.org/10.1016/j. tate.2018.03.014

Carr, A., Balasubramanian, K., Atieno, R., \& Onyango, J. (2018). Lifelong learning to empowerment: beyond formal education. Distance Education, 39(1), 69-86. https://doi.org/10.1080/01587919.2017.1419819

Cochrane, T., \& Narayan, V. (2013). Redesigning professional development: reconceptualising teaching using social learning technologies. Research in Learning Technology, 21, 158-169. https://doi. org/10.3402/rlt.v21i0.19226

Cochrane, T., \& Rhodes, D. (2013). iArchi[tech]ture: Developing a mobile social media framework for pedagogical transformation. Australasian Journal of Educational Technology, 29(3), 372-386. https://doi.org/10.14742/ajet.191

Cochrane, T., Sissons, H., Mulrennan, D., \& Pamatatau, R. (2013). Journalism 2.0: Exploring the impact of mobile and social media on journalism education. International Journal of Mobile and Blended Learning, 5(2), 22-38. https://doi.org/10.4018/jmbl.2013040102

Cook, V. S., \& Gregory, R. L. (2018). Emerging technologies: It's not what you say - It's what they do. Online Learning, 22(3), 121-130. https://doi.org/10.24059/olj.v22i3.1463

Deming, D. (2020, April 9). Online learning should return to a supporting role. The New York Times. https://www.nytimes.com/2020/04/09/business/online-learning-virus.html

Durkin-Boyle, L. (2017). Heutagogies' place in prior learning asssessment (PLA). Assessment Update, 29(4), 5-7. https://doi.org/10.1002/au.30100

Eachempati, P., Kumar, K., Komattil, R., \& Ismail, A. R. H. (2017). Heutagogy through Facebook for the millennial learners. MedEdPublish, 6(4), 1-12. https://doi.org/10.15694/mep.2017.000194

Eberle, J. H. (2013). Lifelong learning. In S. Hase \& C. Kenyon (Eds.), Self-determined learning: Heutagogy in action (pp. 145-157). Bloomsbury.

Faherty, A. (2015). Developing enterprise skills through peer-assessed pitch presentations. Education + Training, 57(3), 290-305. https://doi.org/10.1108/ET-02-2014-0013

Filipe, H. P., \& Mack, H. G. (2019). Teaching through social media. Annals of Eye Science, 4(28), 1-11. https://doi.org/10.21037/aes.2019.07.02

Garrison, D. R., Anderson, T., \& Archer, W. (2001). Critical thinking, cognitive presence, and computer conferencing in distance education. American Journal of Distance Education, 15(1), 7-23. https:// doi.org/10.1080/08923640109527071 
Green, J. K., \& Huntington, A. D. (2017). Online professional development for digitally differentiated nurses: An action research perspective. Nurse Education in Practice, 22, 55-62. https://doi.org/ 10.1016/j.nepr.2016.11.009

Green, R. D., \& Schlairet, M. C. (2017). Moving toward heutagogical learning: Illuminating undergraduate nursing students' experiences in a flipped classroom. Nurse Education Today, 49, 122-128. https://doi.org/10.1016/j.nedt.2016.11.016

Gregory, S., \& Bannister-Tyrrell, M. (2017). Digital learner presence and online teaching tools: Higher cognitive requirements of online learners for effective learning. Research and Practice in Technology Enhanced Learning, 12(1), 1-18. https://doi.org/10.1186/s41039-017-0059-3

Gregory, S., Bannister-Tyrrell, M., Charteris, J., \& Nye, A. (2018). Heutagogy in postgraduate education: Cognitive advantages for higher degree online students. In F. F. Padro, R. Erwee, M. A. Harmes, M. K. Harmes, \& P. A. Danaher (Eds.), Postgraduate education in higher education (pp. 189-209). Springer. https://doi.org/10.1007/978-981-10-5249-1_32.

Hase, S. (2009). Heutagogy and e-learning in the workplace: Some challenges and opportunities. Impact: Journal of Applied Research in Workplace E-Learning, 1(1), 43-52. https://doi.org/10.5043/ impact.13

Hase, S., \& Kenyon, C. (2000). From andragogy to heutagogy. ultiBASE. https://webarchive.nla.gov. au/awa/20010220130000/http://ultibase.rmit.edu.au/Articles/dec00/hase2.htm

Hase, S., \& Kenyon, C. (2007). Heutagogy: A child of complexity theory. Complicity: An International Journal of Complexity and Education, 4(1), 111-118. https://journals.library.ualberta.ca/complicity/ index.php/complicity/article/view/8766/7086

Hase, S., \& Kenyon, C. (2013). The nature of learning. In S. Hase \& C. Kenyon (Eds.), Self-determined learning: Heutagogy in action (pp. 19-35). Bloomsbury.

Haworth, R. (2016). Personal learning environments: A solution for self-directed learners. TechTrends, 60(4), 359-364. https://doi.org/10.1007/s11528-016-0074-z

Hill, P. (2020, May 13). The COVID-fueled hybridization of higher education. Phil on EdTech. https:// philonedtech.com/the-covid-fueled-hybridization-of-higher-ed/

Hodges, C., Moore, S., Lockee, B., Trust, T., \& Bond, A. (2020, March 27). The difference between emergency remote teaching and online learning. EDUCAUSE Review. https://er.educause.edu/ articles/2020/3/the-difference-between-emergency-remote-teaching-and-online-learning

Holland, A. A. (2019). Effective principles of informal online learning design: A theory-building metasynthesis of qualitative research. Computers \& Education, 128, 214-226. https://doi.org/ 10.1016/j.compedu.2018.09.026

Jones, C. (2016). Enterprise education: Towards the development of the heutagogical learner. The All Ireland Journal of Teaching and Learning in Higher Education, 8(1), 2541-25417. https://ojs.aishe. org/aishe/index.php/aishe-j/article/view/254/406

Jones, C., Matlay, H., Penaluna, K., \& Penaluna, A. (2014). Claiming the future of enterprise education. Education + Training, 56(8/9), 764-775. https://doi.org/10.1108/ET-06-2014-0065

Jones, C., Penaluna, K., \& Penaluna, A. (2019). The promise of andragogy, heutagogy and academagogy to enterprise and entrepreneurship education pedagogy. Education + Training, 61(9), 1170-1186. https://doi.org/10.1108/ET-10-2018-0211

Kanwar, A. S., Balasubramanian, K., \& Umar, A. (2013). Lifelong learning in South Africa. International Journal of Continuing Education \& Lifelong Learning, 5(2), 17-39.

Knowles, M. S., Holton, E. F., \& Swanson, R. A. (2015). The adult learning: The definitive classic in adult education and human resource development (8th ed.). Routledge.

Kovanović, V., Joksimović, S., Poquet, O., Hennis, T., Čukić, I., de Vries, P., Hatala, M., Dawson, S., Siemens, G., \& Gašević, D. (2018). Exploring communities of inquiry in massive open online courses. Computers \& Education, 119, 44-58. https://doi.org/10.1016/j.compedu.2017.11.010

Kozan, K., \& Caskurlu, S. (2018). On the $\mathrm{N}^{\text {th }}$ presence for the Community of Inquiry framework. Computers \& Education, 122, 104-118. https://doi.org/10.1016/j.compedu.2018.03.010

Kubalíková, A., \& Kacian, A. (2016). Twenty-five years of continuing professional development of teachers in the post-communist era in Slovakia: The story of paths not taken. Professional Development in Education, 42(5), 836-853. https://doi.org/10.1080/19415257.2015.1114958 
Kumar, S., \& Ritzhaupt, A. D. (2014). Adapting the community of inquiry survey for an online graduate program: Implications for online programs. E-Learning and Digital Media, 11(1), 59-71. https://doi.org/10.2304/elea.2014.11.1.59

Liberati, A., Altman, D. G., Tetzlaff, J., Mulrow, C., Gøtzsche, P. C., loannidis, J. P. A., Clarke, M., Devereaux, P. J., Kleijnen, J., \& Moher, D. (2009). The PRISMA statement for reporting systematic reviews and meta-analyses of studies that evaluate health care interventions: Explanation and elaboration. PLoS Medicine, 6(7), 1-28. https://doi.org/10.1371/journal.pmed.1000100

Links, M. J. (2018). Beyond competency-based continuing professional development. Medical Teacher, 40(3), 253-258. https://doi.org/10.1080/0142159X.2017.1401219

Meckler, L., Strauss, V., \& Heim, J. (2020, April 13). Millions of public school students will suffer from school closures, education leaders have concluded. The Washington Post. https://www.washing tonpost.com/local/education/online-learning-summer-school-coronavirus/2020/04/11/ de11c278-7adc-11ea-a130-df573469f094_story.html

Moore, R. L. (2014). Information architecture for social media: A case study on building an event backchannel with Twitter. International Journal of Social Media and Interactive Learning Environments, 2(1), 21-36. https://doi.org/10.1504/IJSMILE.2014.059690

Moore, R. L. (2016). Interacting at a distance: Creating engagement in online learning environments. In L. Kyei-Blankson, J. Blankson, E. Ntuli, \& C. Agyeman (Eds.), Handbook of research on strategic management of interaction, presence, and participation in online courses (pp. 401-425). IGI Global. https://doi.org/10.4018/978-1-4666-9582-5.ch016

Moore, R. L., \& Fodrey, B. P. (2018). Distance education and technology infrastructure: Strategies and opportunities. In A. Pina, V. Lowell, \& B. Harris (Eds.), Leading and managing e-learning (pp. 87-100). Springer. https://doi.org/10.1007/978-3-319-61780-0_7

Moore, R. L., Oliver, K. M., \& Wang, C. (2019). Setting the pace: examining cognitive processing in MOOC discussion forums with automatic text analysis. Interactive Learning Environments, 27(5-6), 655-669. https://doi.org/10.1080/10494820.2019.1610453

Mulrennan, D. (2018). Mobile social media and the news: Where heutagogy enables journalism education. Journalism \& Mass Communication Educator, 73(3), 322-333. https://doi.org/10.1177/ 1077695817720762

Nadelson, L. S., Berg, W., Fox, B., Grandbouche, P., Harris, M., Kroschel, T. L., \& Sandoval, S. (2017). Snap, tweet and post: College student social media perceptions and heutagogic practices and uses. International Journal of Higher Education, 6(4), 11-27. https://doi.org/10.5430/ijhe. v6n4p11

Naqvi, T. F., \& Parvez, J. (2019). Considering heutagogy as an innovative approach for skill development. SocialSci Journal, 3, 1-7.

Narayan, V., Herrington, J., \& Cochrane, T. (2019). Design principles for heutagogical learning: Implementing student-determined learning with mobile and social media tools. Australasian Journal of Educational Technology, 35(3), 86-102. https://doi.org/10.14742/ajet.3941

Noguchi, Y. (2020, March 17). Coronavirus triple duty: Working, parenting, and teaching from home. All Things Considered. https://www.npr.org/2020/03/17/816631571/coronavirus-triple-dutyworking-parenting-and-teaching-from-home

Pal, R. K., \& Roy, N. R. (2019). Hitting the bull's eye: Designing the process of implementation of heutagogy to empower the adult learners. Suraj Punj Journal for Multidisciplinary Research, 9(5), 486-495. http://spjmr.com/gallery/51-spjmr-1002.final.pdf

Reynolds, M. (2020, April 25). Teacher connects with students using social media during COVID-19 pandemic. KAIT 8. https://www.kait8.com/2020/04/25/teacher-connects-with-students-usingsocial-media-during-covid-pandemic/

Shah, D. (2018, January 8). By the numbers: MOOCs in 2017. Class Central. https://www.class-central. com/report/mooc-stats-2017/

Speight, S. (2018). The mainstreaming of massive open online courses (MOOCs). In M. Milana, S. Webb, J. Holford, R. Waller, \& P. Jarvis (Eds.), The Palgrave international handbook on adult and lifelong education and learning (pp. 939-956). Palgrave Macmillan. https://doi.org/10.1057/ 978-1-137-55783-4_48 